\title{
THE LIFE AND CAREER OF JOHN WEBSTER
}

John Webster was born in 1611, the son of Edward Webster of Thornton-on-the-Hill in the parish of Coxwold, Yorkshire. ${ }^{1}$ According to Anthony Wood, the young Webster spent some time at Cambridge, though his name does not appear in the extant records of the University. In 1634, he was ordained as a minister of the Church of England and was appointed curate to the remote northern parish of Kildwick in his native Yorkshire. Within a year of his appointment, however, Webster seems to have fallen foul of the clerical authorities, and in 1637, he was finally deprived of his living, a victim, in all probability, of the anti-puritan purge of Richard Neile, Archbishop of York. ${ }^{2}$

Webster was no puritan in the orthodox sense of the word. Unlike many of his radical contemporaries, he did not undergo a long and tortuous route through the various sects of mid-seventeenth-century England, nor did he seem to support the cause of mainstream puritan reform in the period before 1642. His first experience of non-conformity was, in fact, with a group of radical sectaries, the Grindletonians, who preached inter alia perfectionist doctrines and attacked the established church and its learned ministry. Webster had encountered this group in the mid-1630s when, according to his own subsequent account, he first became aware of "the sad experience of mine own dead, sinful, lost and damnable condition". In the circumstances, it is hardly surprising that his occupancy of the living of Kildwick was so short-lived and that he was forced, as a result of his dismissal in 1637 , to seek elsewhere for employment. ${ }^{3}$

During the 1640s, two callings in particular caught the imagination of Webster's unsettled mind: medicine and teaching. He was probably practising medicine on a part-time basis throughout the 1640s, and his skills were certainly employed in 1648 , when he enlisted as a surgeon in the parliamentary regiment of Colonel Shuttleworth. Prior to this appointment, Webster had taken up residence in the Lancashire town of Clitheroe, where from 1643 to 1648 he was employed as a schoolmaster in the local grammar school. Neither of these pursuits, however, proved capable of restraining Webster's deep religious yearnings, for in 1647, he was intruded into the living of

\footnotetext{
1 The article by Bertha Potter in the Dictionary of national biography (hereinafter DNB), London, Oxford University Press, 22 vols., 1921-22, vol. 22, pp. 1036-1037, gives the year of Webster's birth as 1610 . For this correction and much other valuable information concerning the life of Webster, I am indebted to two hitherto neglected articles by William Self Weeks in the Transactions of the Lancashire and Cheshire Antiquarian Society (hereinafter TLCAS), 1921, 39: 55-107; and 1932, 47: 30-59.

2 Anthony Wood, Athenae Oxonienses, edited by P. Bliss, Oxford, F.C.\&J. Rivington, 4 vols., 1813-20, vol 4, col. 250; Ronald A. Marchant, Puritans and the church courts in the diocese of York, 1560-1642, London, Longmans, 1960, pp. 127-128, 290.

${ }^{3}$ John Webster, The saints guide, London, Giles Calvert, 1653,sig.A3v. For Grindletonian beliefs, including the rejection of clerical ordination, see Christopher Hill, The world turned upside down, London, Temple Smith, 1972, pp. 65-68.
} 
Mitton, just four miles from Clitheroe, which he held for the next two years. Clearly, the change in the political and religious mood of the country after 1647 assisted Webster's apparent rapprochement with the church. On the other hand, there is no evidence to suggest that he received or accepted a stipend for the cure of Mitton. Not only was he reported at this time to preach gratis to the people of Grindleton, but for much of the period in question he must have been absent from Mitton because of his involvement in the second civil war. Whatever the case, in 1649 , he finally decided to sever all ties with the established church and returned to Clitheroe where, with one notable exception, he lived until his death in $1682 .{ }^{4}$

That exception was Webster's appearance in London in 1653, when he briefly achieved a certain notoriety for his radical views on the church and universities. Webster was almost certainly attracted to the capital in this year because of his conviction, shared by many others in 1653 , that the long-awaited millennium was about to break forth in Cromwell's England. The meeting of the Barebones Parliament in July 1653 promised radical reform in all areas of English life and many, including Webster, undoubtedly envisaged its convocation as the prelude to the imminent return of Christ to his earthly legacy. The radicals, however, were deeply divided on the crucial issue of the nature of this future kingdom of Christ, and Webster himself rejected the popular view that Christ would return in person to reign over the saints. On the contrary, throughout his published works and sermons dating from this period, Webster strongly intimated that the prophetical vision of St John was not intended to presage real events. It was rather to be understood as a powerful allegory of the age-old spiritual struggle between good and evil which, very soon, would be concluded in the heart and soul of every Christian. ${ }^{5}$

Shorn of its literal meaning, the biblical account in Revelation nonetheless lost none of its urgent, cataclysmic significance for Webster, who now believed that the long-expected day of universal spiritual renewal was close at hand. Moreover, in the light of Webster's subsequent denial of traditional demonological beliefs (see below, pp. 7-14), his eschatological notions in this period are highly illuminating. In sermon after sermon, Webster insisted that the concept of evil possessed no physical shape or form, nor was it circumscribed within any fixed locality. The Devil and hell were thus intended as synonyms for the depraved condition of the human soul, which ever since the fall of Adam had been covered by a "vail of darkness". In the struggle to overcome this "vail", Webster stressed that coveted human attributes such as power, physical strength, and learning were of no use. Though they seemed to offer man security

\footnotetext{
${ }^{4}$ For Webster's association with Clitheroe Grammar School in the 1640 s, and his subsequent spell as a governor (1660-62), see especially C.W. Stokes, Queen Mary's grammar school: Part I. The sixteenth and seventeenth centuries, Publications of the Chetham Society, new series, no. 92, Manchester, 1934, pp. 97-128, 140-141. As Weeks demonstrates, there is little evidence to support the view of Charles Webster and others that Webster retired "to a living in his native Yorkshire after 1653"; C. Webster, The great instauration. science, medicine and reform, 1626-60, London, Duckworth, 1975, pp. 83, 188-189, 193; W.S. Weeks, 'John Webster, author of The displaying of supposed witchcraft', TLCAS, 1921, 39: 77-84 and passim. Webster himself wrote in 1653 that he was "no Dean nor Master... neither have I tyths appropriate, nor impropriate, augmentation, nor State pay", Academiarum examen, or the examination of academies, London, G. Calvert, 1654, sig.A5r (preface to the reader dated 21 October 1653).

${ }^{5}$ For thestrength of millenarian opinion at this time, see Bernard S. Capp, The fifthmonarchymen: astudy in seventeenth-century English millenarianism, London, Faber \& Faber, 1972, pp. 50-75.
} 
against eternal damnation, and so helped to put off "the Evil day from him", they were in reality "a Covenant with Death and Hell". Only when man turned to Christ, argued Webster, was he able to determine the full extent of his misery and the depraved condition of his soul, for then, "he sees that there is in him Antichrist indeed, the beast with seven Heads and ten Horns, and himself bearing the Mark and Image of the Beast". 6

The outcome of this personal, spiritual millennium was the destruction of all established human values, which were irrevocably turned upside down so that man's wisdom was now accounted folly, "his Righteousness, Sin; . . . his Heaven, Hell". To the regenerate saint nothing was sinful, but to those still labouring under the ordinances of the Old Testament, the "veil was unrent" and continued to obscure man's understanding, not only of himself but also of the creation. In a passage of remarkable clarity, Webster thus enunciated the full implications of his simple, uncomplicated antinomianism when he wrote that, "in the Day that the Soul turns to the Lord, . . . then is the Caul of the Heart rent, then is Hell laid open in him, and the bottomless Gulf seen in himself: And that Hell men so much talk of, he sees to be really in himself, and that himself is the very Image of the Devil". 7

Webster's antinomianism was a short step to the view that it was possible to live in a perfect state of grace in this world rather than wait, as most clergymen taught, for the uncertain reward of an after-life. A man in such a condition was not only released from the bondage of human edicts in religion, but he was also instantaneously restored to the state of perfect innocence once enjoyed by Adam in Eden, one aspect of which was the latter's comprehensive and intuitive knowledge of the creation. Whether or not Webster submitted entirely to such doctrines in the 1650s is unclear (though one should not forget his early acquaintance with this kind of thinking in the mid-1630s, above p. 1). What is certain, however, is that he did envisage vast intellectual gains for mankind in the event of a millenial revolution of the human spirit. This much is clear from his well-known views on education and the reform of higher learning in Cromwellian England, and is especially evident in the case of his advocacy of the search for the "universal language of nature", which many saw as the key to the secrets of the creation. In 1654, under the influence of the Silesian mystic, Jacob Boehme, Webster thus described this language of nature as the "Paradisical language of the outflown word which Adam understood while he was unfaln in Eden" and which was "infused into him in his Creation and so innate ... and not inventive or acquisitive". Lost at the Fall, the only hope of its recovery was that in this present "age of the spirit" it might once again be revealed to man through the merciful gift of divine inspiration and so heal the breach between man and the rest of nature. ${ }^{8}$

\footnotetext{
${ }^{6}$ John Webster, The vail of the covering, spreadover all nations, 2nd ed., London, J. Sowle, 1713, pp. 6-8, 25. The original sermon was delivered at All Hallows, Lombard Street on 23 June 1653, and was subsequently published in The judgement set, and the bookes opened, London, R. Hartford \& N. Brooks, 1654.

${ }^{7}$ Webster, The vail of the covering, pp. 27, 38-39 (my italics). In another sermon preached at this time in London, Webster expounded at great length upon the idea that "there is no greater Deceiver to be found then is within Man: No cunninger Devil, no greater ANTICHRIST, nor no worse WITCH then what Man hath in his own heart". He went on to say that "however man is carried out to look for all these things without him, yet be sure these Sorcerers, these Wizzards, these Necromancers . . Devils, Antichrists, all are in thine own bosome. Here is the true Necromancy and Witchcraft, the true Antichrist," The judgement set, pp. 159-161; cf. below pp. 11-12.

8 John Webster, op. cit., note 4 above, pp. 25-32.
} 
Clearly, Webster's religious, educational, and scientific beliefs were closely interrelated, his attack on the universities in 1654 (but written in 1653) being in large part a product of his radical theological stance. By the early 1650 s, Webster would seem to have rejected the authority of all sects, churches, and religious organizations. In his writings, he consistently put forward the view that any attempt to intellectualize or institutionalize man's relationship with God was a perversion of divine will. It is impossible to say when exactly Webster arrived at this conclusion, though much that he wrote during this period tends to indicate a long history of disillusionment with, and dissent from, established religion ("the chains and fetters of cold and dead formality"). What is certain is that by 1653 at the latest he was a vociferous opponent of state-supported religion, be it episcopal, presbyterian, or independent, and an equally committed advocate of comprehensive religious toleration. A member of no specific sect, he would seem, therefore, to have shared the semi-mystical seeker opinions of his colleague, William Erbery, with whom he preached in an infamous debate at All Hallows Church in Lombard Street in October $1653 .^{9}$

Alongside Erbery and others, Webster argued that all men must be free to interpret the scriptures and seek God's grace according to the light of their own consciences. Any attempt by the secular or ecclesiastical authorities to use coercion in such matters was considered "antichristian" by Webster, based as it was on the false premise that divine wisdom was acquired through human assistance (e.g., learning and preaching) rather than infused by the free gift of God's grace. The true way to salvation was thus to be found in the pursuit of faith alone and without recourse to human reason-a view to which many mainstream puritans paid lip-service in the period before 1640, despite the obvious heretical pitfalls of such a position. As John Morgan has shown, however, any apparent ambiguity in puritan circles concerning the role of reason in religious experience was firmly resolved by subordinating reason to faith and allowing only a limited role for the former in the acquisition of grace. For Webster, on the other hand, no such fine scholarly distinctions between "infused" and "acquired" learning was allowable in matters relating to salvation, for: "if man gave his assent unto, or believed the things of Christ, either because, and as they are taught of and by men, or because they appear probable and consentaneous to his reason, then would his faith be statuminated upon the rotten basis of humane authority". 10

Indeed, Webster reminded the scholastic theologians of the universities that such a dichotomy or division between the two kinds of learning ("infused" and "acquired") had first been taught in the academies by their own predecessors. His aim in all this was

\footnotetext{
${ }^{9}$ Ibid., sig.A2r. The debate with Erbery and two anonymous defenders of the state church was first reported in Mercurius Politicus, no. 175, 13-20 October 1653, pp. 2795-2796. Webster replied in The picture of Mercurius Politicus, London, T. Webster \& R. Hammond, 1653. Webster's friendship with William Erbery, whom he referred to as "chemist of truth and gospel", tends to strengthen the view that Webster at this time was immersed in perfectionist doctrines of a most radical hue. In 1658, he defended Erbery from the charge of Ranterism, insisting that Erbery's doctrine concerning the "restitution of all things, the liberty of the Creation, and Saints oneness in Christ with God" had been misinterpreted by "some weaker spirits". Needless to say, it was also alleged of Erbery that he denied the existence of eternal damnation, heaven and hell, and the Devil; see William Erbery, The testimony of William Erbery, London, G. Calvert, 1658, pp. 259, 260; Hill, op. cit., note 3 above, pp. 154-159.

10 John Morgan, Godly learning: Puritan attitudes towards reason, learning, and education 1560-1640, Cambridge University Press, 1986; John Webster, op. cit., note 4 above, pp. 12-13, 17.
} 


\section{The life and career of John Webster}

to refute once and for all the idea that grace and redemption might somehow be attained through the mere efforts of men. As Webster and his radical associates never tired of explaining, no amount of learning or biblical study could ensure possession of the gift of divine grace. On the contrary, such efforts were more likely to obscure rather than enlighten the minds of the sinful. Theology as taught in the schools was therefore obsolete in Webster's eyes, and the fact that such wisdom was considered essential to the training of the Anglican clergy merely increased the likelihood for Webster that the Anglican church was no true church of Christ. ${ }^{11}$

If one turns to examine Webster's detailed plan of reform for higher learning in England, it would seem logical to expect, given Webster's pronounced fideism, that the guiding principle of reform would be a secular curriculum devoid of religious content. That this was not the case is due almost entirely to the fact that Webster, in common with other radicals, was wholly oppposed to the retention of a system of learning dependant upon non-Christian sources. Academiarum examen (1654) should therefore be seen as an attempt by Webster to construct a reformed Christian epistemology in which the liberal arts, philosophy, science, and medicine were all represented albeit in purified form. Moreover, in this scheme Webster fully appreciated the possibility that all learning could, and should, be adapted to complement the pursuit of a holy, Christian existence. Neither was it necessary or even desirable for wisdom "acquired" in this manner to be divorced completely from spiritual or religious concerns. On the contrary, as Webster intimated in a sermon preached in June 1653, the divine creation was a constant witness to the eternal truths of Christianity: "there is not any one thing in the World but it holds forth Jesus Christ : all the whol creation is a representation of Jesus Christ: all tipes, all metaphors are resemblances of him". ${ }^{12}$

The application of such knowledge to overtly religious ends was always permissible in Webster's eyes as long as (a) it did not contradict the basic tenets of the Christian faith, and (b) it was not taught in such a way as to imply that herein lay the key to the mysteries of salvation. ${ }^{13}$ Moreover, within the realm of "acquired" learning itself, it seems that Webster may have envisaged a qualitative distinction between experimental and rational modes of enquiry with far greater emphasis placed upon the virtues of the former. Consequently, pride of place in the new curriculum was reserved for men such as Paracelsus and van Helmont, Jacob Boehme and Robert Fludd, whose theosophical speculations were always more likely, for Webster, to repair the intellectual damage caused by the fall. All of these men had to some extent denigrated the faculty of human reason in scientific endeavour whilst promoting the benefits to mankind of experiential or experimental wisdom. More importantly, they all suggested the existence of an intimate relationship between experimenter and Creator whereby knowledge was perceived in part as the product or gift of divine providence. Whether or not Webster subscribed fully to the view that all knowledge was the product of divine inspiration is open to question (cf. for example his interest in the re-discovery of the Behmenist

\footnotetext{
${ }^{11}$ Ibid., pp. 3-18.

12 Webster, op. cit., note 6 above, p. 10.

${ }^{13} \mathrm{Cf}$. the view of the Paracelsian translator and religious radical, Henry Pinnell, that "every part of the Creation doth its part to publish the great mysteries of mans Salvation", Philosophy reformed and improved in four profound tractates, London, Lodowick Lloyd, 1657, sig.A6v.
} 
language of nature, above, p. 3). What is beyond doubt is the relative significance that he personally attached to those schools of thought which imbibed gnostic beliefs. $^{14}$

Given such a preference, it is not surprising that Webster, throughout his life, consistently rejected an over-reliance upon human reason. In Academiarum examen, he poured scorn on those "unexperienced Authors" who slavishly followed the "ancients" in all aspects of learning, and he failed to understand how anyone could hope to "fathome the Universe by our shallow imaginations, or comprize the mysteries of mother nature in the narrow compass of our weak brains". Twenty years later, in the very different atmosphere of restoration England, Webster continued to decry speculative learning, and he remained especially contemptuous of "the Dark-lanthorn of Mans blind, frail and weak reason", which he believed was still the object of excessive veneration. Among those who continued to "idolize humane abilities and carnal reason" were the churchmen and philosophers who "not only applied those so much magnified Engines to the discovery of created things, wherein they have affected so little, [but] have also ... invaded Heaven, and taken upon them to discover and determine of Celestials". ${ }^{15}$

Iconoclasm of this kind, dating as it does from Webster's later years, would seem to suggest that Webster never fully abandoned the radical principles upon which his personal faith was built, despite the fact that he conformed after 1660 . One reason for his apparent quietism is almost certainly to be found in the profound sense of disillusionment that Webster experienced following the collapse of millenarian hopes in the mid-1650s. The failure of the millennium to materialize, as Webster explained in 1658 , was a sign to the "saints" that "the restitution of all things is put afarr off". Webster now realized that he was no longer living in the promised age of "deliverance", but rather in the "time of bondage" so that "the Saints running from Mountain to Hill, is rather an exchange of one bondage for another then any reall redemption from the Ancient Yoke". Consequently, Webster reasoned that the "saints" had a duty to recognize the altered circumstances of the time and to adopt a "carriage" or attitude commensurate with their new position. Accordingly, he cautioned submission to the powers-that-be and, citing his ex-colleague Erbery as an example, he counselled that "it was the Wisdom, as well as the obedience of the Saints, to make their Captivity as comfortable as they could; [for] to shake off the yoke before the season came, was to rebel against the Lord". ${ }^{16}$

That Webster was referring here to his own situation, rather than that of his dead friend Erbery (d.1654), is borne out by the details of his life following his return to Clitheroe in the mid-1650s. By 1657, he had acquired sufficient property, much of it sequestered land, to qualify for the office of in-bailiff or resident magistrate to the town

\footnotetext{
14 Webster quoted van Helmont to the effect that "the Lord had created the Physician, not theSchools", op. cit., note 4 above, p. 76.

${ }^{15}$ Ibid., p. 68; Webster, The displaying of supposed witchcraft, London, J.M., 1677, pp. 138, 201. By the 1670 s, however, Webster's view of the traditional function of the universities had apparently softened, since he now condemned those who had "grown so rigid and peremptory, that they will condemn all things that have not past the test of Experiment ... . and so would totally demolish that part of Academick and Formal Learning that teacheth men Method and the way of Logical procedure". Ibid., p. 20.

${ }^{16}$ Erbery, op. cit., note 9 above, sigs. alv-a2r (preface by J[ohn] W[ebster]).
} 
of Clitheroe, and he held the post on three subsequent occasions $(1658,1665,1675)$. He was also at this time well settled in a busy medical practice, which allowed him the luxury of an apprentice as well as an excuse to indulge his life-long passion for alchemical research. Clearly, Webster had become resigned to the fact that the revolutionary millenial moment or "season of deliverance" had passed, and that it was now his duty to adapt in the best way possible to the religious and political realities of life in interregnum England. Complete submission to the powers-that-be, regardless of what form they might take, was now the order of the day, a view which Webster seemed to find easy to translate to this period of rapidly shifting religious and political loyalties. $^{17}$

Even the restoration of Charles II in 1660 posed few problems for Webster, whose record under the new regime was one of exemplary loyalty. In the elections to the Cavalier Parliament in 1661, Webster voted for the royalist candidate Ambrose Pudsay, and four years later, he was once again magistrate for Clitheroe, an office which he could only have held by conforming to the restored church. Such actions may, of course, have been prompted by considerations that had little relation to political idealism, particularly since Webster had acquired large amounts of royalist land in the 1650 s. On the other hand, there is no reason to suppose that Webster was anything but sincere in his new-found regard for the monarchy, which as he intimated in 1658, was probably just as acceptable to the defeated "saints" as any other form of political authority. ${ }^{18}$

Convinced of the futility of further attacks upon the religious and political authorities, Webster thus abandoned the radical cause and began to pour his considerable energies into less controversial pursuits. In particular, more and more of his time was devoted to the study of "Experimental Philosophy" and "mysticall Chymistrye". Interest in these areas of enquiry not only formed the basis of his last two published works but also, in all likelihood, provided some form of spiritual consolation and solace for the ex-radical. In 1671, appeared Metallographia, or, an history of metals, a work recently described as "arguably the most effective work in its area produced by an English writer before 1700". Based on wide reading and a firm understanding of Paracelsian and Helmontian sources, it also reflects Webster's own practical involvement in alchemical research. Finally in 1677, at the age of sixty-six, Webster published The displaying of supposed witchcraft, a work highly critical of traditional demonological beliefs, which, in some quarters, must surely have revived memories of Webster's earlier reputation as a controversialist. ${ }^{19}$

Why Webster should have felt compelled to write on such a thorny subject as witchcraft in the 1670 s is a matter for conjecture. There can be little doubt that the

\footnotetext{
${ }^{17}$ Weeks, op. cit., note 4 above, pp. 67-76, 90-97. Webster's last known involvement in religious controversy concerned a dispute with the local Independent minister, Thomas Jolly, between 1654 and 1656; see Henry Fishwick (editor), The note book of the Rev. Thomas Jolly . . Extracts from the church book of Altham and Wymondhouses, Publications of the Chetham Society, new series, no. 33, Manchester, 1895, pp. 126, 128.

${ }_{18}$ W.S. Weeks, 'Further information about Dr. John Webster', TLCAS, 1932, 48: 30-59, esp. pp. 37-46.

19 Charles Webster, From Paracelsus to Newton: magic and the making of modern science, Cambridge University Press, 1982, p. 71. At his death, John Webster owned "Chimicall glasses" to the value of $£ 4$, as well as a "furnace house". See Appendix 1.
} 


\section{The library of John Webster}

work itself was the product of a life-long interest in such matters, and that much of the material for the book was collected over many decades. ${ }^{20}$ But why risk public censure and further controversy after twenty years of self-imposed restraint? One possible explanation lies in Webster's enthusiastic reception of the Royal Society, which he described in 1671 as "one of the happy fruits of his Majesties blessed and miraculous Restoration". In the same year, a Durham schoolmaster, Peter Nelson, in the course of a regular correspondence with the secretary of the Royal Society, Henry Oldenburg, referred to Webster as "a man very fit for your Correspondence". Nelson claimed to have made Webster's acquaintance "about 7 or 8 yeares agoe" [i.e., in 1663 or 1664], was aware of his radical past, but was nonetheless convinced of his potential use to the fledgling Society. It is just possible, therefore, that when Nelson wrote three years earlier to Oldenburg, in 1668, requesting to "see something from the Royall Society about Spirits and Witches" that he already had Webster in mind for the job. ${ }^{21}$

Though one cannot be certain of Nelson's precise role, if any, in the origins of The displaying, his view of witchcraft as "none of the most obvious things in Nature", which hitherto had been "discours't of with ye least of clearness and satisfaction", was surely one which Webster would have endorsed. ${ }^{22}$ Whatever the case, a draft copy of the completed work was presented to the Royal Society as early as February 1674, and it was subsequently published in 1677 with the imprimatur of the Society's vice-president, Sir Jonas Moore. Despite the fact that Webster had no official ties with the Society, he did possess one vital ally and supporter in the shape of the Yorkshire naturalist and Fellow, Martin Lister. In January 1674, Webster had written to Lister requesting his assistance in "the licenseing of my booke", which had evidently met with strong disapproval in certain quarters. A month later, Webster sent Lister a draft copy of the frontispiece to The displaying along with an outline or "register" of chapters, and in an accompanying letter he explained the nature of his current problems with regard to publication. ${ }^{23}$

According to Webster, the "Ecclesiasticks" were refusing to license the work on the grounds that "I have attributed too much to naturall causes" as well as "maintaineing falne Angells to be corporeal". Under the circumstances, Webster felt obliged to send a copy to the Royal Society in the hope that it might be licensed there, and was now writing to Lister in the hope that he might "write to some of your friends there to further it". In the event that this strategy should prove unsuccessful, Webster went on to say that he was prepared, if necessary, to "habit it in Latine" and "get it printed beyond seas"- a sure indication if any were needed that the ageing physician had lost none of his contempt for intellectual authoritarianism. ${ }^{24}$

\footnotetext{
${ }^{20}$ Webster first encountered witchcraft in the mid-1630s when, as rector of Kildwick, he helped toexpose the fraudulent practices of the local witch-finder, Edmund Robinson. A copy of the examination of Robinson is attached to the rear of Webster's Displaying.

${ }^{21}$ Webster, Metallographia:or, anhistoryofmetals, London, WalterKettilby, 1671,sig.A2v;A.R.and M.B Hall (editors), The correspondence of Henry Oldenburg, Madison and Milwaukee, University of Wisconsin Press, 1965-77, 11 vols., vol. 5, p. 24, vol. 7, pp. 534-535. Nelson also wrote to Oldenburg on the subject of fabulous prodigies and natural marvels (ibid., vol. 7, p. 535; vol. 9, p. 615), local iatrochemists (ibid., vol. 7, p. 326), and his own moderate and tolerant religious proposals (ibid., vol. 9, p. 616).

22 Ibid., vol. 7, p. 24.

${ }^{23}$ Thomas Birch (editor), The history of the Royal Society of London, London, A. Millar, 1756-57, 4 vols. vol. 3, p. 192; Bodleian Library, Oxford, Lister MS. 34, ff. 145, 147-148.

24 Ibid., f. 148.
} 
Opinions vary as to the overall significance of Webster's contribution to the witchcraft debate in seventeenth-century England, and the work itself still awaits comprehensive analysis. ${ }^{25}$ It was clearly intended as a reply to the familiar arguments of the demonologists, which had recently been resurrected by two well-respected Anglican clergymen, Meric Casaubon (1599-1671) and Joseph Glanvill (1636-80). Not surprisingly, the religious background of these two men, compared with Webster's own, has prompted speculation as to the underlying purpose of The displaying and its place in the general context of post-restoration religious polemic. ${ }^{26}$ Casaubon, in particular, was an obvious target for Webster's pen. ${ }^{27}$ Glanvill's appearance, however, in the witchcraft debate on the side of the traditionalists was presumably more problematic for Webster, given Glanvill's well-publicized religious moderation as well as his enthusiastic support for the "new science" and the Royal Society. One solution to this problem, proposed by Thomas Jobe, has focused on an attempt to maximize the intellectual gap between the two protagonists by portraying Glanvill and Webster as the typical representatives of two competing religio-scientific paradigms:

The witchcraft debates took the form of a struggle between two kinds of science-ParacelsianHelmontian science versus a mechanical corpuscularianism - but behind that struggle lay the clash of the theologies to which these sciences were linked-radical protestant versus orthodox Anglican theology. The Glanvill-Webster exchanges thus should be viewed as a continuation into the Restoration of the debate between radical Protestants and latitudinarian Anglican theologians that began in the $1650 \mathrm{~s}^{28}$

Although such an analysis is superficially appealing, and may well reflect the situation before 1660 , as an explanation for the underlying motives in the postrestoration debate on witchcraft it undoubtedly over-simplifies what is a highly complex situation. Not all Paracelsians or Helmontians, for example, shared Webster's scepticism on such issues, nor was there unanimity among the members of the Royal Society as to belief in the reality of witches and demons. ${ }^{29}$ It is equally improbable to suppose that hermetic science appealed exclusively to radical protestants, or that mechanical corpuscularianism was the special preserve of latitudinarian Anglicans. As to Webster's radical protestantism, there is little evidence in The displaying to suggest that he was consciously pursuing a theological controversy that had its roots in the interregnum. Indeed, in composing this work, Webster may well have employed many

${ }^{25}$ G.L. Kittredge, for example, was completely unable to see how Webster might "be regarded as a tower of sceptical strength in the great witchcraft controversy"; Kittredge, Witchcraft in old and new England, New York, Russell \& Russell, 1958, pp. 348-349; cf. similar view of R.T. Davies, Four centuries of witch-beliefs, London, Methuen, 1947, p. 185 and n. At the opposite extreme, K. Theodore Hoppen has described Webster's work as "perhaps the most noteworthy contemporary critique of belief in witchcraft"; Hoppen, 'The nature of the early Royal Society', Br.J.Hist.Sci., 1976, 9: 15.

${ }^{26}$ Most notably by Thomas Harmon Jobe,'Thedevilin restoration science: the Glanvill-Webster witchcraft debate', Isis, 1981, 72: 343-356.

${ }^{27}$ An opponent of religious "enthusiasm" in the 1650s, Casaubon remained stubbornlyopposed toall forms of religious or intellectual innovation, which he equated with the works of the devil. Webster, in fact, owned a copy of Casaubon's $A$ true and faithful relation of ...Dr. John Dee ... and some spirits, London, T. Garthwait, 1659 [item 40].

28 Jobe, op. cit., note 26 above, p. 344.

${ }^{29}$ This is a complex issue to which I hope to return in the near future. Needless to say, I cannot agree with Garfield Tourney's conclusion that continuing belief in witchcraft in the second half of the seventeenth century was largely the product of the "superstitious state of restoration medicine"; Tourney, "The physician and witchcraft in restoration England', Med.Hist., 1972, 16: 153-154. 
of the arguments and beliefs that had earlier characterized his commitment to radical religion (see below pp. 11-12). It is not possible to deduce from this, however, that The displaying was intended by Webster as yet another thinly disguised broadside against the religious establishment. On the contrary, as I have already tried to show (above pp. 6-7), all surviving evidence points to the inescapable conclusion that Webster had made his peace with the religious authorities some time in the late $1650 \mathrm{~s}$, and thereafter accepted with patient resignation the return of the Anglican church. ${ }^{30}$

If the idea of an underlying clash of theologies is largely immaterial to our understanding of The displaying, what of Jobe's inference that Webster and Glanvill were somehow engaged in a long-standing dispute between two irreconcilable paradigms of science? Again, the evidence is unconvincing, since it seriously ignores the extent to which Webster's scientific outlook, as expounded in The displaying and confirmed by the contents of his library, was based on a thorough-going eclecticism. This is evident, for example, in his praise for the achievements of Harvey and Bacon, Galileo and Descartes, as well as his genuine admiration for the scientific endeavours of the gentlemen of the Royal Society. It is equally apparent in his tendency to utilize any evidence, including that drawn from the "mechanical-corpuscularian school", which might lend added credence to his own views on witchcraft. ${ }^{31}$

When Webster wrote The displaying in the early 1670s, there is no reason to suppose that he was deliberately seeking to revive memories of his earlier allegiance to religious radicalism, or that he was attempting to discredit non-occult schools of scientific thought. On the other hand, because his approach to witchcraft was so obviously shaped by his earlier attachment to unorthodox religious and scientific ideas, it would be foolish to ignore their part in the final draft of The displaying. ${ }^{32}$ This is particularly evident in the case of Webster's passionate concern for iatrochemistry and "mystical philosophy", which, if no longer considered entirely faultless, still remained a vital ingredient of his overall intellectual outlook. Of Paracelsus, for example, Webster wrote in The displaying that he was unfairly attacked by his detractors, not only for his reasonable dismissal of Galenism, "but also for striving to purge and purifie the ancient, natural, laudable and lawful Magick from the filth and dregs of Imposture .... and Superstitions". At the same time, the Englishman, Robert Fludd, was held to be "one of the most Christian Philosophers that ever writ", whilst pride of place in this pantheon of scientific Gods was reserved for John Baptist van Helmont, "a person of profound judgment, great experience, general learning, high reputation, and now generally followed as the Chief-Standard-bearer for Philosophy, Physick and Chemistry". ${ }^{33}$

\footnotetext{
${ }^{30}$ For example, as in-bailiff for Clitheroe in 1665, Webster must have conformed to the restored Anglican church because of the provisions of the Corporation Act of 1661 .

${ }^{31}$ Webster, op. cit., note 15 above, pp. 3-9, 14-16, 88, 268. Two leading English representatives of the "mechanical-corpuscularian school" were cited by Webster in The displaying: Robert Boyle (p. 251) and Thomas Willis (pp. 313, 315, 316-317).

32 It may be significant that Webster's interest in religious radicalism and occult science coincided roughly with his first encounter with witchcraft, i.e., between 1634 and 1635 . For Webster's induction into "mystical Philosophy" and chemistry through the teachings of Johannes Huniades, see Webster, op. cit., note 21 above, p. 161. This means that Webster must have spent some time in London around 1635, since Huniades was resident in the Whitechapel district of the city. For Huniades, see F. Sherwood Taylor and C.H. Josten, 'Johannes Banfi Hunyades 1576-1650', Ambix, 1953, 1956, 5: 44-52, 115.

${ }^{33}$ Webster, op. cit., note 15 above, pp. 9, 259; cf. Webster, op. cit., note 21 above, pp. 34-35.
} 
In eulogizing the achievements and thought of such men, Webster was inevitably drawn into the defence of some of their methods, which were themselves cited by the demonologists as evidence of the reality of witchcraft (e.g., the weapon-salve). Webster's reply to such insinuations was based firmly upon the Helmontian assertion that nature itself was completely devoid of "contrariety" or malign intentions and so could not be held responsible for the evil ends to which men might use it. The creation was brought into being by God for the benefit of all mankind, "his Creatures . . . all made to show forth his power and Godhead". It was therefore inconceivable that it might possess any trait or attribute that was innately harmful to man. More often than not, Webster concluded, it was man's ignorance of natural causation that lay at the root of continuing belief in witchcraft. Yet the problem remains: to what extent did Webster allow a real role for the Devil in the world of man and nature ? $^{34}$

It has been suggested that Webster was not altogether consistent on this and a number of related points, and that he left significant loopholes in what was otherwise a thoroughly sceptical account of the Devil's ability to interfere in the natural world. ${ }^{35}$ As we shall see, there is certainly an element of truth in such an analysis of The displaying. It is, however, possible to argue that many of these apparent discrepancies can be explained to some extent as due to an understandable reluctance on Webster's part to accept in full the subversive implications of his earlier adherence to what one might term the "mystical-radical" tradition. Nowhere is this more apparent than in Webster's discussion of the properties and nature of spirits, demons and devils, and their capacity to inflict harm upon men and women. In various passages throughout The displaying, Webster conceded that God did occasionally allow the Devil access to this world, though his liberty to act in such extraordinary circumstances was severely circumscribed. In particular, it was considered inconceivable that any physical contact between men and devils was permitted or possible, despite the fact that Webster positively affirmed the corporeal quality of demons and fallen angels. Because the Devil was restricted to "the acts of his wicked and depraved will", collusion was possible between men and the Devil in the form of a mental pact. In reality, however, this did not amount to a great deal, for,

if they object and say, that here we confess a League with the Devil and the Witch, . . we answer, it is a gross mistake, in not observing the distinction we make between a mental and a spiritual League, such as the Devil and Judas made: and such as all wicked men make with him; and under this League we acknowledge all Witches to be; but a visible and corporeal League we positively deny. ${ }^{36}$

In consistently stressing this point - that the only contact between men and the Devil was "mental" or "spiritual"-it is difficult to avoid the conclusion that Webster was drawing upon those ideas which he had held in the 1650 s, and which stated, inter alia, that the Devil was little more than the figurative embodiment of the idea of evil (cf. above pp. 2-3; and n7). Elsewhere in The displaying it is possible to detect further vestiges of Webster's radical past, as, for example, in his defence of "Allegorical, Metaphorical, Mystical and Parabolical Expositions", as well as his deprecation of "too much extolling and idolizing of Humane and Carnal reason".

\footnotetext{
34 Webster, op. cit., note 15 above, pp. 17-18.

${ }^{35}$ See, for example, Charles Webster, op. cit., note 19 above, pp. 97-98.

36 Webster, op. cit., note 15 above, pp. 18, 71 (my italics); cf. ibid., pp. 31, 48, 67, 70, 73-75, 77 and passim.
} 
Finally, the common belief amongst interregnum radicals in an impersonal, symbolic Devil is not altogether absent from Webster's last work, as illustrated by the following allusion to Ephesians, 6, 11-18:

\begin{abstract}
Therefore we are to give heed unto the counsel of the Holy Ghost, to resist the Devil in his spiritual assaults with the spiritual weapons that God bestows upon us, and not to give heed to ... the false Doctrine of Witchmongers, that make us watch for the Devil where he is not, and in the mean time not to resist him where he is, and that is ... effectively in a spiritual manner, for he worketh in the children of disobedience, and therefore a Devil within us is more to be feared, than a Devil without us. $^{37}$
\end{abstract}

On this basis, it was possible to dismiss most instances of supposed diabolism or witchcraft in the Bible as clear examples of mental transactions between man and the Devil. Of this nature were the temptation of Eve by the serpent (Genesis, 3, 1-6) and the account of the Witch of Endor (1 Samuel, 28, 7-25). Similarly, in the New Testament, Christ's enticement by the Devil and his transportation through the air (Matthew, 4, 1-11) were not to be interpreted as real events, but rather as manifestations of Satan's spiritual wickedness and his symbolic role as universal tempter of mankind. ${ }^{38}$ On the one hand then, because "spirits" were essentially corporeal, Webster was loath to dismiss absolutely the hypothetical notion of demonic interference in human affairs. On the other hand, however, he stood by the belief that it was highly unlikely in this present age that God should suffer the Devil to roam the earth freely, since "miracles being long ceased, it must needs follow, that Devils do nothing, but only draw the minds of Men and Women into sin and wickedness". 39

Moreover, if devils did exist in the sub-lunary world, a supposition that Webster never consistently owned, ${ }^{40}$ their ability to perform real and extraordinary feats was drastically curtailed. Not only were they consigned by God to the "Caliginious air or Atmosphere" and so unable without divine permission to punish or harm men, but as impure and material beings, their knowledge of the creation was necessarily imperfect and far less than that claimed by the demonologists. It was therefore a constant theme of The displaying that it was both "vain and needless" to invoke the aid of demons and devils "seeing they have no advantage over us, but operate only by applying active things to passive, like as men do". Even if God did allow the Devil or his agents a special dispensation to intervene in the natural world (as the "School-men, and Divines most generally hold") the outcome remained natural:

\footnotetext{
${ }^{37}$ Ibid.,pp. 138-139,99(my italics). Cf. the view of the Paracelsian and occult philosopher, Robert Turner, that "neither they [i.e., the demonologists] nor any man or woman in the world yet saw his Cloven-foot; but he keeps his schoole in their own bosomes. And therefore St. Paul teaches them how to make their defence against him. That ever there was any such thing as Bill or Bond by any one sealed to him; or any Contract or Covenant by any witch made with him; is impossible to be true"; Turner, Astrologicall opticks, London, J. Allen \& R. Moon, 1655, unpaginated 'To the Reader'. Similar sentiments were expressed by Reginald Scot in The discoverie of witchcraft, London, W. Brome, 1584, pp. 508, 510.

38 Webster, op. cit., note 15 above, pp. 142-150,29-30, 290, 178-179. Other examples can be found at ibid., pp. 83-97 (lycanthropy and the impossibility of diabolical transfiguration); p. 116 (on the biblical text: "rebellion is as the sin of witchcraft", 1 Samuel, 15, 23); p. 240 (diabolic possession).

39 Ibid., p. 278; see also pp. 225, 239, 290.

${ }^{40} \mathrm{See}$, for example, Webster's comment that although there was abundant evidence in the Bible for the ministry of "good angels ... I do not find any one place . . . where plainly and positively any apparition of evil spirits is recorded, or that by any rational and necessary consequence such a visible appearance can be deduced or proved"; ibid., pp. 288-289.
} 


\section{The life and career of John Webster}

"and so killing any person, it is only wicked and diabolical, in regard of the end, which is murther, but what Witchcraft is there in the means and operation?"41

The fact that Webster was somewhat inconsistent in his discussion of the nature of devils and demons was probably a reflection of his own personal faith in the devil-free nature of the age. The era of miracles and similar extraordinary phenomena having long since passed, Webster now confidently affirmed that God was to be found everywhere "by his Power, Essence and Presence, and therefore cannot literally be said to be comprehended in any locality, but after a Metaphorical sense and expression". Furthermore, because God ruled "all things according to the power ... of his own positive and actual will", nature was largely untouched by the hand of the Devil and his minions, who were accordingly "delivered into chains of darkness" to await the Day of Judgement. ${ }^{42}$

With the Devil thus reduced to the role of an impotent onlooker, Webster set out to emphasize the human element in witchcraft and to stress the evil disposition of the witch, which he perceived as the crucial factor in the making of such "Rebels and Traitors against God and Christ". Reversing the demonological commonplace that it was the Devil and not the deluded witch who was responsible for hurting men and beasts, Webster therefore argued that Satan played no part in the performance of maleficia, which were the exclusive product of the witch's corrupted wisdom. In the process, he also felt obliged to defend all knowledge, including magic, from the imputation of diabolism on the grounds that the only meaningful distinction between "types" of knowledge consisted in "the end and use" to which they were put. ${ }^{43}$

If the overall message of The displaying differed little from that first enunciated by Reginald Scot in the sixteenth century, it should not disguise either the originality or significance of Webster's contribution to the witchcraft debate. Dependent to a large extent upon the unorthodox insights of Paracelsus, van Helmont, and other hermetic philosophers, Webster not only refused to acknowledge the traditional superiority of Satan in the sublunary world but, to the horror of his opponents, he rejected the spiritual being of man's arch-adversary. Divested of spiritual form and substance, Satan was consequently powerless to intervene in the natural world except as a tempter of mankind. In the process, witchcraft was redefined by Webster as the deeds of evil men and women who may or may not have been inspired by the Devil in the pursuit of their profane but wholly natural activities.

Despite the ecclesiastical opposition that Webster had spoken of prior to the publication of The displaying in the early 1670s, the work itself produced surprisingly

\footnotetext{
${ }^{41}$ Ibid., pp. 220, 224, 18, 152, 78-79. Webster was, however, inclined to allot a minor role to fallen angels in "the sublunary changes or motions of Meteors . . . as the Christian Philosopher Doctor Fludd hath most learnedly proved"; ibid., p. 222. For Webster's assertion that devils possess physical attributes and corporeal form, see esp. ibid., pp. 197-215.

42 Ibid.,pp. 139-140, 183, 18; cf. John Everard's statement that "in our forefather's days, we have heard that there appeared Spirits and Hobgoblins, and such kind of things; but that was in the days of Popery and blindness ... now the light have vanished all these things"; Everard, Some gospel-treasures opened, London, Rapha Harford, 1653, p. 148. Webster published an 'approbration' to Everard's works, which appeared in the enlarged 1659 edition of Some gospel-treasures opened, and was added to Webster's own The judgement set, pp. 311-312. Everard does not appear, however, in the catalogue of books owned by Webster.

${ }^{43}$ Webster, op. cit., note 15 above, pp. 67, 78, 152 and passim. For Webster's general indebtedness to van Helmont in the formulation of his own scepticism, see ibid., pp. 17, 152-159, 162, 241-266.
} 
little response from the defenders of the orthodox position. Apart from further denunciations by Glanvill and Henry More, and an attack upon Webster's intellectual inconsistency from the pen of the cleric Benjamin Camfield, Webster's views on witchcraft elicited little serious response. ${ }^{44} \mathrm{We}$ may assume, therefore, that the last years of Webster's life were largely untroubled by further controversy. In January 1680 , he made his last will and testament (the details of which suggest a comfortable existence; see Appendix 1), and on 18 June 1682 he died, leaving behind an epitaph that he himself wrote and which now stands in the parish church of Clitheroe. ${ }^{45}$

44 Joseph Glanvill, Saducismus triumphatus ... With aletter of Dr. H. More on the same subject, London, J. Collins \& S. Lownds, 1681; Benjamin Camfield, A theological discourse of angels . . Also an appendix containing some reflections upon Mr. Websters displaying supposed witchcraft, London, Henry Brome, 1678, esp. pp. 178, 197-200.

45 See Appendix 2. 